\title{
O controle jurisdicional dos atos administrativos discricionários*
}

The judicial review of administrative acts discretionary

\author{
Carolline Leal Ribas** \\ Gustavo Almeida Paolinelli de Castro***
}

\section{RESUMO}

Por muito tempo, os atos administrativos discricionários foram vistos como intangíveis à análise do Judiciário no que se refere ao mérito, ou seja, aos critérios de conveniência e oportunidade do administrador. Com fulcro nesse entendimento, entendia-se que o julgador apenas poderia adentrar ao exame de legalidade do ato, de forma a verificar se foram obedecidos os critérios formais imprescindíveis à sua elaboração. Todavia, essa discricionariedade ampla concedida ao administrador dava margem a abusos de poder, interesses pessoais, omissões, injustiças e corrupção.

Artigo recebido em 4 de janeiro de 2012 e aprovado em 7 de junho de 2012.

* Pós-graduanda em direito público pela PUC-Minas. Pontifícia Universidade Católica de Minas Gerais, Belo Horizonte, Minas Gerais, Brasil. E-mail: carollinelr@hotmail.com.

*** Professor orientador, doutorando e mestre em direito público (PUC-Minas). Especialista em direito constitucional - Universidade Castilla La-Mancha (Espanha-2006) e em direito constitucional (Cumih). Graduado em Direito - Universidade Fumec (2003). Professor de graduação do Centro Universitário Uni-BH. Sócio-diretor do Escritório Paolinelli de Castro Advogados Associados. Membro pesquisador do Núcleo Jurídico de Políticas Públicas (Nujup). Pontifícia Universidade Católica de Minas Gerais, Belo Horizonte, Minas Gerais, Brasil. E-mail: gustavopaolinelli@gmail.com. 
Assim, tornaram-se necessárias maiores medidas de controle, a fim de coibir a prática de atos desvinculados do interesse público e contrários aos interesses do estado democrático de direito. Para tanto, confiou-se ao Judiciário o poder de exercer maior controle desses atos, de modo a garantir efetivamente o direito que fora consagrado na Constituição. Tal importe é fruto do contexto histórico da constitucionalização do direito administrativo e do consequente processo de judicialização, eis que a via judicial passou a ser o meio de se concretizar as regras e os princípios constitucionais, muitas vezes não observados pela administração pública, sob o simples argumento que lhe fora conferido o poder discricionário. Assim, uma vez ampliado o controle pelo Judiciário, restou reduzida a discricionariedade administrativa, visto que qualquer ato proferido pelo administrador, seja vinculado ou discricionário, deve observar os ditames da lei bem como os princípios constitucionais (princípio da legalidade em sentido amplo). O presente trabalho, portanto, demonstra a possibilidade de o Poder Judiciário analisar os atos discricionários não apenas sob o aspecto da legalidade, como também do direito, de modo a coibir a prática de atos administrativos contrários à lei ou aos princípios constitucionais e interesse público.

\section{PALAVRAS-CHAVE}

Ato administrativo discricionário - mérito - constitucionalização do direito administrativo - princípios constitucionais - controle jurisdicional

\section{ABSTRACT}

For a long time, the discretionary administrative actions were seen as intangible analysis of the judiciary as to the merits, i.e., the criteria of convenience and opportunity of the administrator. With this core understanding, it was believed that the judge could only enter the examination of the legality of the act in order to see if we followed the formal criteria essential to its development. However, the wide discretion granted to the administrator gave rise to abuses of power, personal interests, omissions, injustice and corruption. Thus, they became more necessary control measures in order to curb the practice of acts unrelated to the public interest and against the interests of a democratic state. To this end, entrusted to the judiciary the power to exercise greater control of these acts in order to effectively guarantee the law that was enshrined in the 
Constitution. This amount is the result of the constitutionalization of the historical context of administrative law and the consequent expansion of the process of legalization, behold, the courts became the means to implement the rules and constitutional principles, not often seen by the public authorities under the simple argument that he had been given the discretion. Thus, once expanded control by the judiciary, remained reduced discretion, since any act given by the administrator, whether linked or discretionary, must follow the dictates of law and constitutional principles (principle of legality in a broad sense). This study therefore demonstrates the possibility of the Judiciary review the discretionary acts not only from the standpoint of legality, but also the law, in order to discourage the practice of administrative acts contrary to law or constitutional principles and public interest.

\section{KEYWORDS}

Discretionary administrative act - merit - constitutionalization of administrative law - constitutional principles - judicial review

\section{Introdução}

No presente estudo pretende-se examinar o controle jurisdicional dos atos administrativos discricionários à luz dos princípios constitucionais previstos na Constituição de 1988.

Para tanto, inicialmente foi necessária uma breve análise da evolução do estado de direito, com a finalidade de apresentar o desenvolvimento do processo de constitucionalização do direito administrativo e da jurisdição. Enfatizou-se a consequente tendência à ampliação do Poder Judiciário, bem como a valoração dos princípios e garantias fundamentais que embasam o estado democrático de direito.

O segundo passo consistiu num estudo das características gerais do ato discricionário de modo a embasar a compreensão para a seção seguinte.

Posteriormente, adentrou-se ao foco da presente contenda. A princípio, retomou-se o contexto histórico do estado democrático de direito, com o objetivo de se demonstrar, com realce, a evolução do princípio da legalidade. Em seguida, procurou-se esclarecer como a discricionariedade e o controle judicial vêm sendo compreendidos hodiernamente. 
O escopo principal repousa sobre a atuação dos juristas no controle de mérito do ato, ou seja, nas razões de conveniência e oportunidade que ensejaram a prática do ato pelo agente da administração. Até onde poderia o Poder Judiciário intervir na discricionariedade?

Para melhor análise, escolheu-se examinar um julgado do Superior Tribunal de Justiça (STJ), o qual retoma a contenda em apreço, tendo servido de embasamento para muitos julgados recentes.

\section{A jurisdição na contemporaneidade: um resgate necessário}

A análise do controle judicial dos atos administrativos não pode dispensar o exame do papel da jurisdição na contemporaneidade. Para levar a cabo tal pretensão, entretanto, é preciso conhecer, ainda que em breves linhas, o desenvolvimento do Judiciário e sua relação com os demais poderes.

O estudo será feito em três momentos históricos distintos, quais sejam: paradigmas liberal, social e democrático.

\subsection{A jurisdição nos paradigmas de estado}

O desenvolvimento do estado de direito deu-se em três fases: o estado liberal de direito, contra o paradigma do Estado absolutista do Antigo Regime; o estado social de direito, em desfavor do individualismo e o abstencionismo do Estado anterior; estado democrático de direito em face da conjuntura sociopolítica do regime anterior: resquícios individualistas, neocapitalismo opressor, sistema estabelecido privilegiado. ${ }^{1}$

Para o presente trabalho, será relevante o estudo dessa evolução a fim de se demonstrar o processo de constitucionalização do direito administrativo, o qual deu ensejo a um novo papel do Judiciário sob a ótica do controle judicial.

1 Verdú apud MENDES, Gilmar Ferreira; COELHO, Inocêncio Mártires; BRANCO, Paulo Gustavo Gonet. Curso de direito constitucional. 4. ed. São Paulo: Saraiva, 2009. p. 66. 


\subsubsection{Período liberal}

O período do liberalismo nasceu no contexto da Revolução Francesa e da Revolução Norte-Americana, no século XVIII. Essa época representou a vitória da proposta econômica liberal da burguesia, resultando na redução do papel do Estado e na valorização do indivíduo. ${ }^{2}$

Nesse período, a classe burguesa passou a deter o poder político, fundamentado em leis constitucionais que representariam a soberania popular em detrimento da grandeza dada ao Estado no período anterior.

As constituições liberais, de tal modo, declaravam os direitos individuais, vez que estes regulam e protegem as condutas contra o Estado, o que revela, a seu turno, que o limite do direito de um sujeito é o direito do outro. ${ }^{3}$

Ressalta-se, ainda, que nessa fase surgiu a concepção de separação dos poderes, uma vez que as funções estatais agora não mais se concentrariam num poder absoluto e concentrado, tal como fora no estado de polícia. Ressaltam-se as palavras de Fagundes:

O Estado, uma vez constituído, realiza os seus fins por meio de três funções em que se reparte a sua atividade: legislação, administração e jurisdição. A função legislativa liga-se aos fenômenos de formação do direito, enquanto as outras duas, administrativa e jurisdicional, se prendem à fase de sua realização. Legislar (editar o direito positivo), administrar (aplicar o direito de ofício) e julgar (aplicar a lei contenciosamente) são três fases da atividade estatal, que se completam e se esgotam em extensão. ${ }^{4}$

Contudo, é imperioso ressaltar que o Poder Legislativo, neste período da história, era dotado de supremacia, colocando os outros dois poderes sob a égide da lei. Isso porque apenas o legislador poderia editar as leis, sendo-lhe vedado delegar esse poder. ${ }^{5}$

2 MAGALHÃES, José Luiz Quadros de. Direito constitucional. 2. ed. Belo Horizonte: Mandamentos, 2002. p. 62-63.

Ibid., p. 63.

4 FAGUNDES, Miguel Seabra. O controle dos atos administrativos pelo Poder Judiciário. 8. ed. Rio de Janeiro: Forense, 2010. p. 3.

5 DI PIETRO, Maria Sylvia Zanella. Discricionariedade administrativa na Constituição de 1988. São Paulo: Atlas, 1991. p. 15. 
Assim, pode-se dizer que no Estado liberal o direito foi visto como uma ordem, um sistema fechado de regras, visto que as leis, uma vez gerais e abstratas, garantiam os direitos subjetivos de cada indivíduo. ${ }^{6}$

Foi nesse contexto que se consagrou o princípio da legalidade, vez que ninguém poderia ter sua liberdade restrita senão em virtude de lei. ${ }^{7}$

Como consequência, a administração pública se vinculava à legalidade em sentido estrito, podendo fazer tudo o que a lei não lhe proíba, o que restou conhecido como "vinculação negativa da Administração". ${ }^{8}$

Desse modo, naqueles pontos não regulados pela lei poderia o poder público atuar conforme sua discricionariedade, a qual era considerada um campo insusceptível de controle judicial. ${ }^{9}$

O Poder Judiciário, por sua vez, se limitava a dirimir conflitos interparticulares ou entre estes e a administração, adequando o caso concreto à vinculação ao sentido literal da lei. ${ }^{10}$

No sistema brasileiro, o período liberal foi marcado pela Constituição de 1891, a qual estremou o papel do Legislativo na função de elaborar as leis, bem como o papel da administração, dando-lhe amplo poder discricionário, apenas podendo sofrer limites expressamente previstos em lei. ${ }^{11}$

O cenário liberal, entretanto, passou por sérias alterações e críticas, vez que esse paradigma não era mais suficiente para garantir os direitos e liberdades dos indivíduos.

Assim, tornou-se necessário uma maior intervenção do Estado, como meio de superar o individualismo e proporcionar uma ampliação dos direitos sociais. ${ }^{12}$

6 OLIVEIRA, Marcelo Andrade Cattoni de. Direito constitucional. Belo Horizonte: Mandamentos, 2002. p. 57-58.

7 Maria Sylvia Zanella Di Pietro, Discricionariedade administrativa na Constituição de 1988, op. cit., p. 15.

8 Ibid., p. 19.

9 Ibid.

10 Marcelo Andrade Cattoni de Oliveira, Direito constitucional, op. cit., p. 57.

11 DI PIETRO, Maria Sylvia Zanella. Direito administrativo. 23. ed. São Paulo: Atlas, 2010. p. 29-30.

12 Diaz apud Gilmar Ferreira Mendes, Inocêncio Mártires Coelho e Paulo Gustavo Gonet Branco, Curso de direito constitucional, op. cit., p. 68. 


\subsubsection{Período social}

As mudanças ocorridas no período após a Primeira Guerra Mundial trouxeram uma nova concepção de estado de direito, vez que se tornou necessário incluir no mundo jurídico os direitos sociais como meio de superar o individualismo exacerbado do período anterior.

No entendimento de Bonavides:

O auge da crise vem documentado pela Constituição de Weimar. As declarações de direitos, as normas constitucionais ou normasprincípios, não importa o teor organizativo ou restritivo que possam ter, se volvem basicamente para a Sociedade e não para o indivíduo; em outros termos, buscam desesperadamente reconciliar o Estado com a Sociedade, intento cuja consequência imediata estampa o sacrifício das teses individuais. Logrou-se esse sacrifício em uma batalha travada por duas teses constitucionais; uma, a do Estado liberal, em decadência; outra, a do Estado social, em ascensão. ${ }^{13}$

Com efeito, alargaram-se as funções estatais, de forma que o Estado passou a intervir nas atividades econômicas e sociais, mas ainda assim respeitando os direitos fundamentais do homem, a separação dos poderes, bem como o poder político pertencente ao povo. ${ }^{14}$

No Brasil, pode-se dizer que esse período se iniciou com a Constituição de 1934, a qual ampliou e fortaleceu o poder do Estado para abranger as áreas econômicas e sociais. ${ }^{15}$

Cabe mencionar que nessa época, apesar de a relação entre os três poderes continuar a ser sob o sistema de freios e contrapesos, o Poder Executivo ganha destaque, já que este tinha a autorização para intervir em maiores atividades.

Ademais, referido poder conquistou competência normativa, de forma que passou a editar normas dotadas com força de lei, dentre elas, medidas provisórias, regulamentos autônomos e decretos. ${ }^{16}$

3 BONAVIDES, Paulo. Curso de direito constitucional. 15. ed. São Paulo: Malheiros, 2004. p. 231.

14 CARVALHO, Kildare Gonçalves de. Direito constitucional. 14. ed. Belo Horizonte: Del Rey, 2008. p. 82-83.

15 Maria Sylvia Zanella Di Pietro, Direito administrativo, op. cit., p. 29.

16 Ibid., p. 29-31. 
Tendo em vista que tais normas foram incluídas no conceito de legalidade, este ganhou novo sentido, se estendendo para o âmbito de toda a atuação administrativa. ${ }^{17}$ Com efeito, a administração passou a se vincular ao que a lei lhe permite, o que deu ensejo à doutrina da "vinculação positiva da administração à lei" ${ }^{18}$

Assim, aquela discricionariedade ampla concedida à administração no período anterior passou a ser limitada à lei, de modo que "toda atuação administrativa passou a desenvolver-se dentro de um círculo definido pela lei; fora desse círculo nada é possível fazer" ${ }^{\prime 1}{ }^{9}$

No entanto, esse modelo sofreu críticas por ser insuficiente à promoção da democracia econômica e social, o que levou ao desenvolvimento de um novo modelo, conforme será apontado a seguir. ${ }^{20}$

\subsubsection{O estado democrático de direito: um olhar renovado sobre o papel do Judiciário}

O estado democrático de direito funda-se na participação popular consagrada pela Constituição, a qual estabelece as normas e princípios que devem ser seguidos pelos representantes no poder.

Nesse trâmite, busca-se a concretização dos valores da democracia, conjugados com a liberdade e igualdade no que se refere ao acesso da população aos direitos sociais. ${ }^{21}$

A Constituição é o texto que positiva todos os direitos fundamentais e sociais, instrumentalizando o poder de atuação dos Estados. ${ }^{22}$

Recorre-se às palavras de Streck:

O Estado Democrático de Direito, teria (tem?) a característica de ultrapassar não só a formulação do Estado Liberal de Direito, como também

17 Maria Sylvia Zanella Di Pietro, Discricionariedade administrativa na Constituição de 1988, op. cit., p. 27.

18 Ibid.

19 Ibid., p. 28.

20 Gilmar Ferreira Mendes, Inocêncio Mártires Coelho e Paulo Gustavo Gonet BRANCO, Curso de direito constitucional, op. cit., p. 69.

21 Diaz apud Gilmar Ferreira Mendes, Inocêncio Mártires Coelho e Paulo Gustavo Gonet BRANCO, Curso de direito constitucional, op. cit., p. 69.

22 STRECK, Lênio Luiz. Hermenêutica jurídica e $(m)$ crise: uma exploração hermenêutica da construção do direito. Porto Alegre: Livraria do Advogado, 2004. p. 39. 
a do Estado Social de Direito. (...) A noção de Estado Democrático de Direito está, pois, indissociavelmente ligada à realização dos direitos fundamentais. É desse liame indissolúvel que exsurge aquilo que se pode denominar de plus normativo do Estado Democrático de Direito. ${ }^{23}$

Para o desenvolvimento do presente estudo, cabe analisar o paradigma do estado democrático de direito sob dois enfoques, quais sejam: a constitucionalização do direito administrativo e o processo de judicialização.

No Brasil, a Constituição de 1988 optou pelos princípios próprios do estado democrático de direito, ${ }^{24}$ o que representou uma concepção mais ampla do princípio da legalidade. ${ }^{25}$

Assim, percebe-se uma maior preocupação com os princípios expressos e implícitos estabelecidos no texto constitucional, já que eles consagram valores sociais, como liberdade, moralidade, igualdade, segurança, desenvolvimento, bem-estar, o que demonstra o direito propriamente dito. ${ }^{26}$

Nesse diapasão, todos os poderes - Legislativo, Executivo e Judiciário - devem se submeter não apenas à lei em sentido formal, e sim ao direito, o que engloba todos os princípios estabelecidos na Constituição (princípio da legalidade em sentido amplo). ${ }^{27}$

Em virtude da adoção dos princípios, pode-se dizer que o estado democrático de direito foi caracterizado pelo processo de constitucionalização do direito administrativo, eis que "a lei deixa de ser o fundamento único e último da atuação da Administração Pública para se tornar apenas um dos princípios do sistema de juridicidade instituído pela Constituição" ${ }^{28}$

Tal processo gerou uma ampliação do Poder Judiciário como meio de efetivar os preceitos constitucionais, conforme será demonstrado.

23 Ibid., p. 37-39.

24 Constituição Federal de 1988: “Art. 1º A República Federativa do Brasil, formada pela união indissolúvel dos Estados e Municípios e do Distrito Federal, constitui-se em Estado Democrático de Direito e tem como fundamentos: I - a soberania; II - a cidadania; III - a dignidade da pessoa humana; IV - os valores sociais do trabalho e da livre-iniciativa; V - o pluralismo político. Parágrafo único. Todo o poder emana do povo, que o exerce por meio de representantes eleitos ou diretamente, nos termos desta Constituição".

25 Maria Sylvia Zanella Di Pietro, Direito administrativo, op. cit., p. 29.

26 Maria Sylvia Zanella Di Pietro, Discricionariedade administrativa na Constituição de 1988, op. cit., p. 34 .

27 Ibid.

28 BINENBOJM, Gustavo. Uma teoria do direito administrativo: direitos fundamentais, democracia e constitucionalização. 2. ed. Rio de Janeiro: Renovar, 2008. p. 70. 
No estado democrático de direito não há uma completa separação dos poderes, e sim uma relação de interdependência e harmonia entre eles. ${ }^{29}$ Isso porque cada poder tem sua função dominante e não exclusiva, visto que poderá desempenhar, excepcionalmente, uma função material do outro. Fala-se, de tal modo, em interpenetração ou interdependência dos poderes, uma vez que o princípio da separação não nega a harmonia, coordenação e colaboração dos poderes. ${ }^{30}$

Todavia, nesse contexto, a relação entre os poderes foi redefinida, vez que a efetivação do direito deslocou-se do centro das decisões dos Poderes Legislativo e Executivo para o âmbito do Judiciário. ${ }^{31}$

A via judiciária, conforme leciona Streck, passou a fazer parte da arena política como meio de promover a guarda da vontade geral implícita no direito positivo, especialmente nos textos constitucionais e nos princípios. Assim, pode ser vista como instrumento de resgate aos direitos não realizados, bem como para o desenvolvimento de políticas públicas, de forma a expressar a vontade do direito positivo e dos princípios constitucionais. ${ }^{32}$

Anote-se, segundo o respeitável doutrinador, que o Poder Judiciário passou a ser visto como uma alternativa para o resgate das promessas da modernidade, suprimindo as inércias dos demais poderes, aumentando, pois, o espaço de poder da justiça constitucional. ${ }^{33}$

Nesse trâmite surgiu o processo de judicialização, fruto do novo direito constitucional característico do pós-positivismo. Esse novo paradigma, em desenvolvimento no Brasil desde a Constituição de 1988, reconhece a expansão da jurisdição constitucional bem como a força normativa dada a Carta, fonte que abriga os princípios e as regras jurídicas. ${ }^{34}$

Segundo Barroso, a judicialização consiste justamente no fato de se confiar ao Poder Judiciário a resolução de questões de larga repercussão política ou social. Para o renomado autor, a judicialização envolve a transferência de

29 Constituição Federal de 1988: “Art. 2o São Poderes da União, independentes e harmônicos entre si, o Legislativo, o Executivo e o Judiciário".

30 CARVALHO, Kildare Gonçalves de. Direito constitucional. 14. ed. Belo Horizonte: Del Rey, 2008. p. 169.

31 Lênio Luiz Streck, Hermenêutica jurídica e $(m)$ crise, op. cit., p. 59.

32 Ibid., p. 55-57.

33 Ibid., p. 39-40, 55.

34 BARROSO, Luis Roberto. Neoconstitucionalismo e constitucionalização do direito. O triunfo tardio do direito constitucional no Brasil. Jus Navegandi, Teresina, ano 10, n. 851, p. 3, 1ํo nov. 2005. Disponível em: <http://jus.com.br/revista/texto/7547>. Acesso em: 5 jun. 2012. 
poder das instâncias políticas tradicionais - Congresso Nacional e o Poder Executivo - para juízes e tribunais. ${ }^{35}$

As Cortes recebem o papel de proteger a Constituição como um todo, confiando à via judicial a efetivação da vida democrática e a manutenção da tranquilidade social, por meio do uso dos princípios constitucionais. ${ }^{36}$

A finalidade é justamente efetivar os direitos constitucionais e aplicar os princípios do direito visando reprimir eventuais abusos de poder, arbitrariedade, corrupção, omissões e injustiças cometidas pela administração, observando-se as peculiaridades do caso concreto. Com efeito, o Judiciário adquire a função de proteger a democracia e suas concepções políticas, não podendo ser afastado de apreciar os casos que lhe forem submetidos. ${ }^{37}$

Imprescindível destacar o novo papel conferido ao Judiciário: ${ }^{38}$ prestar efetivamente a jurisdição por meio da intermediação entre as normas constitucionais e a solução do caso concreto, conjugando os princípios e garantias fundamentais estampados na Constituição.

Esse novo papel dos juristas, no entanto, passou a ser questionado no que se refere à ampliação do controle jurisdicional na esfera da administração, em especial, da discricionariedade: pode o Judiciário analisar o mérito dos atos administrativos discricionários?

O presente estudo pretende demonstrar justamente como tem sido a atuação do Poder Judiciário no controle dos atos discricionários proferidos pelos agentes da administração.

35 BARROSO, Luis Roberto. Judicialização, ativismo judicial e legitimidade democrática. Consultor Jurídico, São Paulo, p. 2, 2008. Disponível em: <www.conjur.com.br/ 2008-dez-22/judicializacao_ativismo_legitimidade_democratica $>$. Acesso em: 1o out. 2011.

36 Gilmar Ferreira Mendes, Inocêncio Mártires Coelho e Paulo Gustavo Gonet Branco, Curso de direito constitucional, op. cit., p. 166.

37 Constituição Federal de 1988: “Art. 5o Todos são iguais perante a lei, sem distinção de qualquer natureza, garantindo-se aos brasileiros e aos estrangeiros residentes no País a inviolabilidade do direito à vida, à liberdade, à igualdade, à segurança e à propriedade, nos termos seguintes: $[\ldots]$

XXXV - a lei não excluirá da apreciação do Poder Judiciário lesão ou ameaça a direito".

38 Foi nesse contexto que surgiu a denominação "ativismo judicial". Para Barroso, a "ideia de ativismo judicial está associada a uma participação mais ampla e intensa do Judiciário na concretização dos valores e fins constitucionais, com maior interferência no espaço de atuação dos outros dois Poderes". BARROSO, Luis Roberto. Judicialização, ativismo judicial e legitimidade democrática, op. cit., p. 4. Tal concepção destaca justamente a confiança que se depositou à nova magistratura como meio de se resgatar as promessas inseridas na Constituição. Gilmar Ferreira Mendes, Inocêncio Mártires Coelho e Paulo Gustavo Gonet Branco, Curso de direito constitucional, op. cit., p. 80. 
Essa discussão, entretanto, não pode ser levada adiante sem uma análise do ato administrativo discricionário, conforme a seguir, posto que objeto indispensável à compreensão dessa contenda.

\section{Dos atos administrativos discricionários}

A lei não é capaz de prever em seu texto todas as hipóteses de atuação administrativa. Por esse motivo, o próprio legislador deixou certa margem de atuação diante de um caso concreto, de modo que cabe à autoridade optar por uma dentre várias soluções possíveis, sendo todas elas válidas perante o direito. ${ }^{39}$

Nesse tocante, surge o poder discricionário. Segundo o doutrinador Mello:

Discricionariedade, portanto, é a margem de liberdade que remanesça ao administrador para eleger, segundo critérios consistentes de razoabilidade, um dentre pelo menos dois comportamentos cabíveis, perante cada caso concreto, a fim de suprir o dever de adotar a solução mais adequada a satisfação da finalidade legal, quando, por força da fluidez das expressões da lei ou da liberdade conferida no mandamento, dela não se possa extrair objetivamente, uma solução unívoca para a situação vertente..$^{40}$

Extrai-se desse conceito que a discricionariedade amplia o campo de liberdade do administrador, vez que este pode escolher seu conteúdo, seu destinatário, sua conveniência, sua oportunidade e o modo de sua realização. ${ }^{41}$ Tal fato lhe confere um juízo subjetivo quanto a sua maneira de proceder nos casos concretos. $^{42}$

Nesse sentido, a doutrina criou o termo mérito do ato, o qual consiste na ponderação dos aspectos relativos à conveniência e oportunidade que inspiraram a prática do ato pelo agente da administração. ${ }^{43}$

39 Maria Sylvia Zanella Di Pietro, Direito administrativo, op. cit., p. 212.

40 MELLO, Celso Antônio Bandeira de. Discricionariedade e controle jurisdicional. 2. ed. São Paulo: Malheiros, 2010. p. 48.

41 MEIRELLES, Hely Lopes. Direito administrativo brasileiro. 36. ed. São Paulo: Malheiros, 2010. p. 172.

42 Celso Antônio Bandeira de Mello, Discricionariedade e controle jurisdicional, op. cit., p. 9, 17.

43 CARVAlHO FILHO, José dos Santos. Manual de direito administrativo. 10. ed. Rio de Janeiro: Lumen Juris, 2003. p. 103. 
No que se refere à conveniência, segundo Moreira Neto citado por Gasparini, pode-se entender o que ocorre quando o "conteúdo jurídico de um ato convém à produção de um resultado que, em tese, está adequado ao atendimento de sua finalidade" ${ }^{44}$

Já oportunidade, para o respeitável doutrinador, ocorre quando, "considerados os pressupostos de fato e de direito, o momento da ação é o adequado à produção desse resultado que, em tese, atende sua finalidade" ${ }^{45}$

A discricionariedade existe em casos quando a lei expressamente confere à administração tal poder, quando a lei é omissa ou quando a lei prevê determinada competência, mas não estabelece a conduta a ser adotada. ${ }^{46}$ Nessas hipóteses o agente administrativo deverá atuar de acordo com o que for mais conveniente e oportuno, porém nunca deixando de observar os parâmetros legais e o interesse público.

Deve-se frisar, nessa oportunidade, uma análise do momento da prática do ato discricionário, bem como dos seus elementos, com o objetivo de se demonstrar em quais aspectos há maior ou menor margem de liberdade ao administrador.

Quanto ao momento, é possível conferir liberdade ao agente administrativo. Caso a lei não estabeleça um momento determinado para a prática do ato, dúvidas não há quanto à liberdade conferida ao administrador para que este escolha o momento mais adequado para a consecução do fim almejado. Caso a lei estabeleça algum prazo, não obstante haja uma limitação de tempo para a prática do ato, ainda sim é possível haver discricionariedade, pois, nesse período determinado, a autoridade escolhe o que lhe parecer mais conveniente. $^{47}$

Nos aspectos da competência, forma ${ }^{48}$ e finalidade, a opinião da maioria dos doutrinadores é que há vinculação, não havendo qualquer liberdade ao administrador, já que este não tem margem alguma de escolha na prática do ato.

44 Moreira Neto apud GASPARINI, Diógenes. Direito administrativo. 8. ed. São Paulo: Saraiva, 2003. p. 91.

45 Moreira Neto apud ibid.

46 Maria Sylvia Zanella Di Pietro, Direito administrativo, op. cit., p. 213.

47 Ibid., p. 213-214.

48 Ibid., p. 214-215. A autora ressalva que há hipóteses em que se permite exame discricionário do ato. São os casos em que a lei prevê mais de um meio de se praticar um mesmo ato, como, a exemplo, a ciência do interessado, podendo ser, quando a lei permitir, dada por meio de publicação ou de notificação direta. Logo, apesar de haver previsão em lei, o agente é que irá optar pela forma mais adequada in casu. 
Quanto ao motivo e ao objeto (conteúdo), a doutrina e a jurisprudência vêm entendendo que há discricionariedade, vez que tais requisitos oferecem um momento de ampla cognição, já que se trata de uma decisão baseada na conveniência e na oportunidade administrativa. ${ }^{49}$

No primeiro caso, não obstante a inexistência de um motivo preestabelecido pela legislação, apenas se devem aceitar os atos implicitamente admitidos pela norma, observando, no caso concreto, se a situação fática está em sintonia com a finalidade legal. ${ }^{50}$

Di Pietro ${ }^{51}$ explica que a discricionariedade quanto aos motivos pode se dar em duas situações: quando a lei não definir o motivo ou quando, ao defini-lo, utilizou-se de conceitos vagos e imprecisos.

Na hipótese de a lei não definir o motivo, caberá ao agente agir nos limites do que é razoável, podendo, por meio da sua competência e da finalidade ora almejada, reconhecer perante quais circunstâncias ela é utilizável, de forma a respeitar os motivos implícitos na lei. ${ }^{52}$

No caso da existência de conceitos vagos e imprecisos, grande parte da doutrina faz referência aos conceitos jurídicos indeterminados a fim de justificar os motivos pelos quais há discricionariedade. São indeterminados porque a lei definiu seus motivos por meio de expressões vagas ou vocábulos plurissignificativos. ${ }^{53}$ Tendo em vista a abstração desses conceitos, o administrador tem uma liberdade para atuar in concreto, não para decidir ao seu talante, e sim para decidir-se de modo que torne possível o alcance perfeito do desiderato normativo. ${ }^{54}$

No caso do objeto ou conteúdo, haverá discricionariedade quando a lei estabelecer vários objetos possíveis para que seja atingido um mesmo fim, sendo qualquer um deles válido perante o ordenamento jurídico. ${ }^{55}$

49 ZIMMER JÚNIOR, Aloísio. Curso de direito administrativo. 3. ed. Porto Alegre: Verbo Jurídico, 2009. p. 189.

50 MELLO, Celso Antônio Bandeira de. Curso de direito administrativo. 26. ed. São Paulo: Malheiros, 2009. p. 392.

51 Maria Sylvia Zanella Di Pietro, Direito administrativo, op. cit., p. 215.

52 Celso Antônio Bandeira de Mello, Discricionariedade e controle jurisdicional, op. cit., p. 92-94.

53 Maria Sylvia Zanella Di Pietro, Direito administrativo, op. cit., p. 215.

54 Celso Antônio Bandeira de Mello, Curso de direito administrativo, op. cit., p. 430. Carvalho Filho, todavia, entende que "a discricionariedade não pressupõe imprecisão de sentido, como ocorre nos conceitos jurídicos indeterminados, mas, ao contrário, espelha a situação jurídica diante da qual o administrador pode optar por uma dentre várias condutas lícitas e possíveis". José dos Santos Carvalho Filho, Manual de direito administrativo, op. cit., p. 37.

55 Maria Sylvia Zanella Di Pietro, Direito administrativo, op. cit., p. 216. 
Como consequência, tal objeto ou conteúdo é traçado pelo agente do ato, mediante avaliação dos elementos que constituem critérios administrativos. ${ }^{56}$ Desse modo, a liberdade conferida ao administrador constitui o mérito administrativo, vez que o objeto fica na dependência do Poder Público. ${ }^{57}$

Cabe mencionar nesse ponto as palavras de Fagundes:

Noutros casos, a lei deixa a autoridade administrativa livre na apreciação do motivo ou do objeto do ato, ou de ambos ao mesmo tempo. No que respeita ao motivo, essa discrição se refere a ocasião de praticálo (oportunidade) e a sua utilidade (conveniência). No que respeita ao conteúdo, a discrição está em poder praticar o ato com objetivo variável, ao seu entender. Nesses casos, a competência é livre ou discricionária. ${ }^{58}$

Por fim, ressalta-se, todavia, que há limitações concernentes ao poder discricionário. Não há dúvidas de que a finalidade do ato é atender ao interesse público, com respaldo na lei. Com efeito, "um dos fatores exigidos para a legalidade do exercício desse poder consiste na adequação da conduta escolhida pelo agente à finalidade que a lei expressa". ${ }^{59}$

Nesses moldes, percebe-se que a atuação discricionária não é totalmente livre visto que a lei em alguns aspectos, tais como quanto a competência, forma e finalidade, conforme já exposto, impõe limitações que devem ser seguidas pelo agente administrativo. ${ }^{60}$

Ocorre que muitas vezes utiliza-se erroneamente a discricionariedade. Tal hipótese recai quando o administrador incide em quaisquer condutas que indiquem desvio de poder, interesse pessoal, corrupção, dentre outros. Nesses casos, referidos atos serão considerados arbitrários, devendo, portanto, ser banidos do sistema jurídico.

Nesse sentido, não poderia o administrador, com base na simples alegação de mera conveniência ou oportunidade, atuar como um árbitro, agir fora dos limites da lei ou com ofensa a esta. ${ }^{61}$ Ademais, além dos limites

56 José dos Santos Carvalho Filho, Manual de direito administrativo, op. cit., p. 91.

57 Hely Lopes Meirelles, Direito administrativo brasileiro, op. cit., p. 158.

58 Miguel Seabra Fagndes, O controle dos atos administrativos pelo Poder Judiciário, op. cit., p. 92.

59 José dos Santos Carvalho Filho, Manual de direito administrativo, op. cit., p. 34.

60 Maria Sylvia Zanella Di Pietro, Direito administrativo, op. cit., p. 212.

61 José dos Santos Carvalho Filho, Manual de direito administrativo, op. cit., p. 35. 
previstos em lei, todos os atos administrativos devem observar os princípios e mandamentos constitucionais, sob pena de invalidação. ${ }^{62}$

O uso indevido da discricionariedade, por consequência, permite que o ato seja passível de revisão pela própria administração e pelo Judiciário. ${ }^{63}$ O primeiro caso trata-se de controle interno, realizado pela entidade ou órgão ora responsável no âmbito da administração pública interna. ${ }^{64}$

Por outro lado, o controle jurisdicional dos atos discricionários é alvo de grandes discussões doutrinárias e jurisprudenciais no que se refere ao controle de mérito, o que será estudado com mais detalhes nos termos a seguir.

\section{O controle jurisdicional dos atos administrativos discricionários}

Esclarecidas as questões acerca dos atos discricionários, imprescindíveis à compreensão do presente estudo, passa-se, por fim, à análise do controle judicial, em face da constitucionalização do direito administrativo e da evolução do estado de direito, consoante fora demonstrado no início do presente trabalho.

Tal controle vem sendo ampliado, permitindo ao Poder Judiciário reexaminar todos os atos, sob a ótica dos princípios constitucionais. ${ }^{65}$ Surge então

62 PEGORARO, Luiz Nunes. Controle jurisdicional dos atos administrativos discricionários. Campinas, SP: Servanda Editora, 2010. p. 114.

63 Súmula no 473 do STF: A administração pode anular seus próprios atos, quando eivados de vícios que os tornam ilegais, porque deles não se originam direitos; ou revogá-los, por motivo de conveniência ou oportunidade, respeitados os direitos adquiridos, e ressalvada, em todos os casos, a apreciação judicial.

64 Luiz Nunes Pegoraro, Controle jurisdicional dos atos administrativos discricionários, op. cit., p. 72.

65 Há de se destacar que princípios e regras são normas jurídicas. Para Canotilho, os princípios "são normas jurídicas impositivas de uma otimização, compatíveis com vários graus de concretização, consoante os condicionalismos fáticos e jurídicos". CANOTILHO, José Joaquim Gomes. Direito constitucional. 6. ed. Coimbra: Almedina, 1993. p. 167. Continua o respeitável doutrinador: "são normas que exigem a realização de algo, da melhor forma possível, de acordo com as possibilidades fáticas e jurídicas. Os princípios não proíbem, permitem ou exigem algo em termos de tudo ou nada; impõem a otimização de um direito ou de um bem jurídico, tendo em conta a reserva do possível, fática ou jurídica". Ibid., p. 534. Já as regras "são normas que prescrevem imperativamente uma exigência (impõem, permitem ou proíbem) que é ou não é cumprida". (Ibid., p. 167-168). As regras correspondem a determinações no campo do possível fático e juridicamente, de modo que, uma vez válidas, se exige o seu cumprimento pleno, não podendo o agente fazer mais nem menos do que elas obrigam, Alexy apud PEDRON, Flávio Quinaud. Algumas considerações sobre a interpretação de Robert Alexy sobre a tese da única resposta correta de Ronald Dworkin. Âmbito Jurídico, Rio Grande, n. 19, 
a indagação a respeito de qual o limite desse controle exercido pelo Poder Judiciário, questão esta exposta a seguir.

\subsection{Da legalidade estrita à análise de mérito do ato: a extensão do controle judicial}

A doutrina clássica, embasada nas lições de Fagundes, estabelece uma dicotomia entre a legalidade ${ }^{66}$ e o mérito do ato administrativo. Assim explica o respeitável doutrinador citado:

O mérito está no sentido político do ato administrativo. É o sentido dele em função das normas da boa administração, ou, noutras palavras, e, ao mesmo tempo, o ajusta aos interesses privados, que toda medida administrativa tem de levar em conta. ${ }^{67}$

A análise da legalidade (legitimidade dos autores italianos) tem um sentido puramente jurídico. Cinge-se a verificar se os atos da Administração obedeceram as prescrições legais, expressamente determinadas, quanto à competência e manifestação da vontade do agente, quanto ao motivo, ao objeto, a finalidade, e a forma. ${ }^{6}$

Para os autores convencionais, o campo da legalidade se restringe ao exame da adequação do ato ao texto legal. Lado outro, o aspecto do mérito embasa-se nos critérios de oportunidade e conveniência do ato praticado, vez que o agente da administração busca ponderações valorativas, emitindo, pois, juízos subjetivos de valor. ${ }^{69}$

Nesse trâmite, o ato vinculado é aquele analisado sob o aspecto da legalidade, enquanto o ato discricionário é dotado dos aspectos legalidade

30 nov. 2004. Disponível em: <www.ambito-juridico.com.br/site/index.php?n_link=revista_ artigos_leitura\&artigo_id=4999>. Acesso em: $1^{\circ}$ out. 2011.

66 O princípio da legalidade está estampado no art. 5, II da Constituição Federal de 1988, o qual reza que "ninguém será obrigado a fazer ou deixar de fazer alguma coisa senão em virtude de lei". Para Gilmar Mendes, tal princípio traduz a ideia de que lei é o instrumento por excelência de conformação jurídica das relações sociais. Gilmar Ferreira Mendes, Inocêncio Mártires Coelho e Paulo Gustavo Gonet Branco, Curso de direito constitucional, op. cit., p. 180.

67 Miguel Seabra Fagundes, O controle dos atos administrativos pelo Poder Judiciário, op. cit., p. 180.

68 Ibid., p. 182.

69 CRETELLA JÚNIOR, José. Curso de direito administrativo. 18. ed. Rio de Janeiro: Forense, 2003. p. 255. 
e mérito, vez que, além do fato de estar em conformidade com a lei, deve-se buscar a conveniência e oportunidade em prol do interesse público. ${ }^{70}$

Com efeito, a doutrina e a jurisprudência vinham adotando o posicionamento de que se o Judiciário analisasse o mérito haveria infringência à separação dos poderes. Veja-se o entendimento empossado na clássica obra de Fagundes: "Ao Poder Judiciário é vedado apreciar, no exercício do controle jurisdicional, o mérito dos atos administrativos. Cabe-lhe examiná-los, tão somente, sob o prisma da legalidade" ${ }^{71}$

Entretanto, esse paradigma vem sendo questionado e caindo em desuso, principalmente no contexto da constitucionalização do direito administrativo, o qual passou a considerar princípios constitucionais como imprescindíveis à prática de qualquer ato administrativo, conforme será demonstrado a seguir.

O conceito de mérito, bem como de discricionariedade, não permaneceu estático ao longo do tempo. Na modernidade, no conhecido estado democrático de direito, os conceitos de legalidade e de mérito são analisados em conjunto, ${ }^{72}$ vez que os aspectos do mérito devem guardar respaldo nos ditames do princípio da legalidade em sentido amplo.

Assim, não há mais, tecnicamente, uma dicotomia entre mérito dos atos discricionários e legalidade, visto que "o antigo mérito do ato administrativo sofre, assim, um sensível estreitamento, por decorrência desta incidência direta dos princípios constitucionais" ${ }^{\prime 3}$

Nesse sentido, afasta-se qualquer contradição entre mérito e legalidade, ${ }^{74}$ já que os critérios de conveniência e oportunidade devem observar não apenas a legalidade em sentido estrito, como também aos princípios constitucionais.

Conforme demonstrado no início do presente estudo, a tendência é ampliar o conceito de legalidade, abrangendo o ideal de justiça embasado no direito, o que deu ensejo ao princípio da legalidade latu senso. Percebe-se que nesse contexto de constitucionalização do direito administrativo, já tratado, os princípios constitucionais foram incluídos no conceito de legalidade em sentido amplo, dentre eles, ressalta-se o princípio da razoabilidade e da proporcionalidade. ${ }^{75}$

70 Maria Sylvia Zanella Di Pietro, Direito administrativo, op. cit., p. 216.

Miguel Seabra Fagundes, O controle dos atos administrativos pelo Poder Judiciário, op. cit., p. 179.

Maria Sylvia Zanella Di Pietro, Direito administrativo, op. cit., p. 30.

3 Gustavo Binenbojm, Uma teoria do direito administrativo, op. cit., p. 71.

74 Luiz Nunes Pegoraro, Controle jurisdicional dos atos administrativos discricionários, op. cit., p. 110.

75 Segundo Mello, o princípio da razoabilidade estabelece que o administrador deve agir conforme os critérios aceitáveis do ponto de vista racional, ou seja, conforme a maioria da população 
Assim, não obstante o ato administrativo seja função ordinariamente da administração, o Judiciário poderia, embora excepcionalmente, adentrar ao mérito do ato a fim de garantir a eficácia e integridade de direitos estampados na Constituição. ${ }^{76}$

Com efeito, o magistrado pode intervir e analisar qualquer ato, caso haja desrespeito a um princípio constitucional e ao interesse público, todos eles hoje jurisdicizados, vez que tal desrespeito ofenderia assim o princípio da legalidade em sentido amplo. ${ }^{77}$

Mais uma vez, recorre-se ao entendimento de Pegoraro: "O controle jurisdicional pela principiologia assume relevância, em razão da qual o juiz vem a exercer talvez a sua mais importante tarefa, de defensor da ordem jurídica". ${ }^{78}$

Desse modo, vertente é que os princípios constitucionais podem reduzir ou limitar a discricionariedade da administração, conforme o caso concreto.

Nesse trâmite, não há dúvidas de que, quanto mais se amplia o conceito de legalidade, mais se reduz a discricionariedade da administração e, lado outro, se amplia o controle judicial. ${ }^{79}$

Assim, a margem de discricionariedade tornou-se estreita, visto que qualquer ato do administrador deve se pautar nos limites da razoabilidade e

faria. Celso Antônio Bandeira de Mello, Curso de direito administrativo, op. cit., p. 108. Com efeito, excluem-se, por serem consideradas ilegítimas e jurisdicionalmente inválidas, as condutas desarrazoadas, bizarras ou inconvenientes, eis que ao contrário do senso normal das pessoas equilibradas. Assim, referido princípio cifra-se na proibição do excesso, o que limita a conduta do administrador, e, por consequência, confere ao julgador a possibilidade de adequação, no caso concreto, do fim eleito e os meios em razão do qual o ato fora praticado. Luiz Nunes Pegoraro, Controle jurisdicional dos atos administrativos discricionários, op. cit. p. 117. Pelo princípio da proporcionalidade entende-se que as condutas administrativas somente podem ser "validamente exercidas na extensão e intensidade correspondentes ao que seja realmente demandado para o cumprimento da finalidade de interesse público a que estão atreladas". Celso Antônio Bandeira de Mello, Curso de direito administrativo, op. cit., p. 110. Ato contínuo, as condutas desproporcionais ao que fora exigível em lei são consideradas ilegais e inadequadas, o que permite que o Judiciário as anule ou as invalide por ofensa à Constituição. Ibid.

76 BRASIL. Supremo Tribunal Federal. RE nํ410.715/AgR/SP.Ag. Reg. no Recurso Extraordinário. Relator ministro Celso de Mello, j. 22/11/2005. Diário de Justiça, Brasília, DF, 10 dez. 2005. Disponível em: <www.stf.jus.br/portal/jurisprudencia /pesquisarJurisprudencia.asp >. Acesso em: 1ㅇo out. 2011.

77 RIO GRANDE DO SUL. Tribunal de Justiça. Jurisprudência. AC no 70021811302 . Des. Adão Sérgio do Nascimento Cassiano. DJ, Porto Alegre, 15 abr. 2008. Disponível em: <www.tjrs.jus. $\mathrm{br} /$ busca/?tb=jurisnova\&partialfields=tribunal $\% 3 \mathrm{ATribunal} \% 2520 \mathrm{de} \% 2520 \mathrm{Justi} \% 25 \mathrm{C} 3 \% 25 \mathrm{~A} 7$ a\%2520do\%2520RS.(TipoDecisao\%3Aac\%25C3\%25B3rd\%25C3\%25A3o I TipoDecisao\%3Amo nocr\%25C3\%25A1tica | TipoDecisao:null)\&t=s\&pesq=ementario.>. Acesso em: 11 nov. 2011.

78 Luiz Nunes Pegoraro, Controle jurisdicional dos atos administrativos discricionários, op. cit., p. 115.

79 Maria Sylvia Zanella Di Pietro, Direito administrativo, op. cit., p. 30. 
da proporcionalidade, além dos critérios de boa-fé, justiça, juízo de igualdade e finalidade da lei. ${ }^{80}$

Nesse sentido, Di Pietro expende seu magistério irrepreensível:

Alargamento do princípio da legalidade, pela adoção dos princípios do Estado Democrático de Direito, trazendo como consequência a maior limitação à discricionariedade administrativa (em decorrência da submissão da Administração Pública a princípios e valores) e a ampliação do controle judicial.

(...) Todos esses princípios e valores são dirigidos aos três poderes do Estado: a lei que os contrarie será inconstitucional; a discricionariedade administrativa está limitada pelos mesmos, o que significa a ampliação do controle judicial, que deverá abranger a validade dos atos administrativos não só diante da lei, mas também perante o Direito, no sentido assinalado.

(...) há a tendência também bastante forte dos chamados "conservadores", calcada no direito positivo e na Constituição, que defende maiores limites à discricionariedade administrativa, exatamente pelo fato de que a sua atuação tem que ter fundamento na lei, mas também tem que observar os limites impostos pelos princípios e valores adotados explícita ou implicitamente pela Constituição. Hoje a discricionariedade é limitada por princípios como os da razoabilidade, proporcionalidade, moralidade, interesse público, impessoalidade, segurança jurídica, sem mencionar os valores inseridos nos artigos $1^{\circ}$ a $4^{\circ}$ da Constituição. ${ }^{81}$

Assim, a discricionariedade passou a ser vinculada não apenas à lei em sentido estrito, tal como era no positivismo jurídico, como também ao direito, o que abrange os princípios que embasam o sistema jurídico vigente. ${ }^{82}$

Os princípios constitucionais, de fato, deram ao julgador o papel de guardião da Constituição, interferindo, inclusive, nas políticas públicas de forma a efetivar os valores nela estampados..$^{83}$

80 FARIA, Edimur Ferreira de. Controle do mérito do ato administrativo pelo Judiciário. Belo Horizonte: Fórum, 2011. p. 156.

81 Maria Sylvia Zanella Di Pietro, Direito administrativo, op. cit., p. 29-31.

82 Maria Sylvia Zanella Di Pietro, Discricionariedade administrativa na Constituição de 1988, op. cit., p. 125.

83 ARENHART, Sergio Cruz. As ações coletivas e o controle das políticas públicas pelo Poder Judiciário. Jus Navigandi, Teresina, ano 10, n. 777, 19 ago. 2005. Disponível em: <http://jus. 
É nesse sentido que a doutrina mais moderna já vem admitindo que, dependendo do caso concreto, a discricionariedade pode ser reduzida a zero, uma vez que os princípios constitucionais poderiam suprir por completo a margem de atuação da administração. Isso porque, em face da escolha de vários tipos de comportamentos, o administrador pode se vincular apenas a uma delas, caso as demais violem algum princípio estabelecido na Constituição. ${ }^{84}$

Como consequência, o controle judicial dos atos administrativos, por meio do uso reiterado dos princípios, passou a ser exercido até mesmo sob o mérito, até então interditos à tutela jurisdicional, desde que observadas as peculiaridades do caso concreto. ${ }^{85}$

\subsection{O controle da discricionariedade na jurisprudência dos tribunais}

Os tribunais têm recorrentemente apreciado a matéria contida neste trabalho, o que demonstra que a discussão quanto à intervenção do Poder Judiciário nos critérios discricionários ainda persiste, tanto no âmbito jurisprudencial quanto no doutrinário. O propósito desta análise é apurar como vem ocorrendo o controle jurisdicional do ato discricionário, com observância aos princípios positivados em âmbito constitucional.

Para tanto, será realizado um estudo de um caso jurisprudencial, de forma a demonstrar como se conjuga referido controle com a discricionariedade administrativa.

com.br/revista/texto/7177/as-acoes-coletivas-e-o-controle-das-politicas-publicas-pelo-poderjudiciario >. Acesso em: $1^{\circ}$ out. 2011. Sem adentrar ao mérito do controle de políticas públicas, eis que, na oportunidade, não consiste no objeto central, cumpre salientar que tanto a doutrina quanto a jurisprudência vêm admitindo maior controle, desde que se verifique alguma lesão a direitos individuais e/ou coletivos. Esclarece o ministro Celso de Mello (Informativo $\mathrm{n}^{\mathrm{o}}$ 345/2004) que a atribuição de instituir e formular políticas públicas constitui um encargo excepcional do Poder Judiciário, eis que inerentes aos Poderes Executivo e Legislativo. Assim, tal incumbência apenas ocorre quando os órgãos estatais descumprirem políticas administrativas ou deixarem de adotar medidas impostas na Constituição, sob o fundamento da "reserva do possível", cabendo ao magistrado, nessas hipóteses, efetivar e concretizar os direitos e garantias estampadas na Constituição (mínimo existencial). BRASIL. Supremo Tribunal Federal, RE no $410.715 / \mathrm{AgR} / \mathrm{SP}$, op. cit.

84 MOTA, Marcel Moraes. Racionalidade e discricionariedade administrativa. Conpedi, Brasília, n. 20, p. 5639, 21/22 nov. 2008. Disponível em: <www.conpedi.org.br/manaus/arquivos/anais/ brasilia/12_178.pdf>. Acesso em: 5 jun. 2012.

85 PEREIRA JUNIOR, Jessé Torres. Controle judicial da administração pública, da legalidade estrita à lógica do razoável. 2. ed. Belo Horizonte: Fórum, 2009. p. 61. 
Por opção metodológica, contida na proximidade do caso com a matéria versada no trabalho, escolheu-se a apreciação do Recurso Especial no 429.570, interposto pelo Ministério Público do Estado de Goiás em desfavor do município de Goiânia, em ação civil pública, objetivando a reforma da decisão de primeiro grau.

A ação foi proposta com o objetivo de obter do Poder Judiciário uma ordem de fazer para que se obrigasse o município, ora recorrido, a recuperar a área degradada por erosões em determinada localidade, as quais estavam causando danos ambientais e risco à população circunvizinha.

O douto juízo a quo entendeu que não caberia ao Judiciário proferir essa tutela de fazer naquele caso, eis que o Poder Executivo possui discricionariedade para decidir sobre a conveniência e oportunidade da realização de obras na região.

Inconformado, o Ministério Público recorreu dessa decisão, sob o principal fundamento de a atividade de recuperação e conservação do meio ambiente consistir em um ato vinculado da administração. Argumentou o parquet, ainda que se entendesse tal ato como discricionário, a doutrina vem admitindo que o Poder Judiciário exerça o controle de legalidade sobre o mérito dos atos discricionários, desde que respeitado o princípio da razoabilidade.

Em 11 de novembro de 2003 o recurso foi julgado, o que ensejou a seguinte ementa:

ADMINISTRATIVO E PROCESSO CIVIL - AÇÃO CIVIL PÚBLICA - OBRA DE RECUPERAÇÃO EM PROL DO MEIO AMBIENTE ATO ADMINISTRATIVO DISCRICIONÁRIO.

1. Na atualidade, a Administração pública está submetida ao império da lei, inclusive quanto à conveniência e oportunidade do ato administrativo.

2. Comprovado tecnicamente ser imprescindível, para o meio ambiente, a realização de obras de recuperação do solo, tem o Ministério Público legitimidade para exigi-la.

3. O Poder Judiciário não mais se limita a examinar os aspectos extrínsecos da administração, pois pode analisar, ainda, as razões de conveniência e oportunidade, uma vez que essas razões devem observar critérios de moralidade e razoabilidade. 
4. Outorga de tutela específica para que a Administração destine do orçamento verba própria para cumpri-la.

5. Recurso especial provido. ${ }^{86}$

Merece destaque uma análise mais apurada do voto da ministra relatora Eliana Calmon, o qual foi acompanhado pelos ministros João Otávio de Noronha e Castro Meira, vencido o ministro Francisco Peçanha Martins.

A ministra relatora trouxe à discussão se caberia à via judicial intervir no ato administrativo ou não. Para tanto iniciou seu voto com a seguinte indagação:

Pode o Judiciário, diante de omissão do Poder Executivo, interferir nos critérios da conveniência e oportunidade da Administração para dispor sobre a prioridade da realização de obra pública voltada para a reparação do meio ambiente, no assim chamado mérito administrativo, impondo-lhe a imediata obrigação de fazer? Em caso negativo, estaria deixando de dar cumprimento à determinação imposta pelo art. 3ํ da lei de ação civil pública? ${ }^{87}$

No caso em análise, primeiramente, há de se destacar que se tem a comprovação de que há um dano objetivo ao meio ambiente.

O poder público, dentro da sua esfera de competência, tem o dever de cessar e reparar os danos causados, o que obriga o Estado a proporcionar a concretização da reparação dos danos ocorridos sob pena de responder civilmente pelos seus atos ou omissões. Nesse sentido, pode-se impor e exigir da esfera administrativa prestações estatais positivas concretizadoras de forma a se garantir a preservação do meio ambiente.

Contudo, tal garantia não pode ter sua eficácia comprometida em razão da inação pelo agente da administração perante suas obrigações constitucionais. Assim, se o Estado deixar de adotar medidas necessárias à realização de preceitos da Constituição, sob o mero fundamento de conveniência e oportunidade, estaria abstendo-se de cumprir o dever que lhe fora imposto, o que constitui uma violação negativa ao texto constitucional. ${ }^{88}$

86 BRASIL. Superior Tribunal de Justiça. REsp no 429.570/GO. 2. T. Relatora ministra Eliana Calmon. Diário de Justiça, Brasília, DF, 22 mar. 2004. Disponível em: <www.stj.jus.br/SCON/>. Acesso em: 1o out. 2011. Grifo nosso.

87 Ibid.

88 Nesse mesmo sentido, ver jurisprudência: BRASIL. Supremo Tribunal Federal. RE no 410.715/ AgR/SP, op. cit. 
Como consequência, caberia ao Poder Judiciário dar sentido concreto à norma, adequando o ato administrativo à finalidade constitucional.

O segundo ponto analisado pela relatora trata da evolução do princípio da legalidade, o qual tem sido interpretado de maneira mais ampla, incluindo os princípios constitucionais.

Para a ministra, não mais se deve interpretar o princípio da legalidade em sentido estrito, vez que tal entendimento significaria uma ampliação do Poder Legislativo. Se assim o fosse, os atos administrativos se vinculariam apenas aos ditames da lei (stricto sensu), enquanto os aspectos de conveniência e oportunidade ficariam totalmente livres à administração.

Com a ampliação do princípio da legalidade, consoante já exposto, a administração pública passou a ter o dever de observar não apenas a lei, como também aos princípios fundamentais. Assim, caso haja abuso ou vulneração a tais princípios pelo administrador, o Judiciário poderia analisar o ato administrativo, com o objetivo não de substituir o administrador, e sim de efetivar princípios positivados em âmbito constitucional.

No caso em análise, a discricionariedade do poder público quanto ao poder de escolha em realizar ou não o ato (recuperar a área degradada por erosões) foi reduzida, vez que foi o Judiciário que determinou a execução de um ato administrativo, não podendo o Executivo negar-se a prestar referido ato. ${ }^{89}$

Cabe salientar, todavia, que foi mantida a discricionariedade quanto à escolha, vez que cabe à autoridade administrativa decidir como será a execução das obras que irão recuperar o meio ambiente degradado..$^{90}$

Desse modo, continua sendo do agente público a competência para agir e realizar a conduta que indique a melhor solução para o caso em questão. ${ }^{91}$

É nesse sentido que se afasta qualquer controvérsia de o Judiciário supostamente estar substituindo o papel do administrador, já que não houve análise dos aspectos não jurídicos do mérito. ${ }^{92}$

Nesse contexto, vale ressaltar as palavras da ministra relatora Eliana Calmon:

A partir da última década do Século XX, o Brasil, com grande atraso, promoveu a sua revisão crítica do Direito, que consistiu em retirar do

89 Gustavo Binenbojm, Uma teoria do direito administrativo, op. cit., p. 235-236.

$90 \quad$ Ibid., p. 236.

91 Edimur Ferreira de Faria, Controle do mérito do ato administrativo pelo Judiciário, op. cit., p. 274.

92 RIO GRANDE DO SUL. Tribunal de Justiça. Jurisprudência. AC no 70021811302, op. cit. 
Legislador a supremacia de superpoder, ao dar nova interpretação ao princípio da legalidade.

Em verdade, é inconcebível que se submeta a Administração, de forma absoluta e total, à lei. Muitas vezes, o vínculo de legalidade significa só a atribuição de competência, deixando zonas de ampla liberdade ao administrador, com o cuidado de não fomentar o arbítrio. Para tanto, deu-se ao Poder Judiciário maior atribuição para imiscuir-se no âmago do ato administrativo, a fim de, mesmo nesse íntimo campo, exercer o juízo de legalidade, coibindo abusos ou vulneração aos princípios constitucionais, na dimensão globalizada do orçamento.

(...) Dentro desse novo paradigma, não se pode simplesmente dizer que, em matéria de conveniência e oportunidade, não pode o Judiciário examiná-las. Aos poucos, o caráter de liberdade total do administrador vai se apagando da cultura brasileira e, no lugar, coloca-se na análise da motivação do ato administrativo a área de controle. E, diga-se, porque pertinente, não apenas o controle em sua acepção mais ampla, mas também o político e a opinião pública.

Na espécie em julgamento, tem-se, comprovado, um dano objetivo causado ao meio ambiente, cabendo ao Poder Público, dentro da sua esfera de competência e atribuição, providenciar a correção. Ao assumir o encargo de gerir o patrimônio público, também assumiu o dever de providenciar a recomposição do meio ambiente, cuja degradação, provocada pela erosão e o descaso, haja vista a utilização das crateras como depósito de lixo, está provocando riscos de desabamento e assoreamento de córregos, prejudicando as áreas de mananciais. ${ }^{93}$

O ministro Francisco Peçanha Martins, todavia, teve seu voto vencido, o qual manteve o posicionamento de não caber ao Judiciário julgar a conveniência e a oportunidade dos atos administrativos, embasando-se nas lições de Seabra Fagundes.

Referido acórdão, embora tenha sido julgado em 11 de novembro de 2003, demonstra uma discussão atual. Os ministros do STJ ainda divergem quanto ao assunto e essa decisão tem orientado vários julgados até os dias atuais.

93 BRASIL. Superior Tribunal de Justiça. REsp no 429.570/GO, op. cit. 
A doutrina, com destaque a Mello ${ }^{94}$ e Di Pietro, ${ }^{95}$ também vem mudando seu posicionamento, abandonando o entendimento de que os atos discricionários são inapreciáveis pela via judicial. ${ }^{96}$

Esse novo pensamento doutrinário entende que Poder Judiciário deve zelar pelos ditames da legalidade em sentido amplo, podendo anular os atos administrativos desde que sejam estes dotados de ilegalidade ou abuso de poder, ou, até mesmo, proferir uma decisão mandamental, embora em hipóteses excepcionais, conforme demonstrado no decisum acima, dependendo do caso concreto.

Isso porque o magistrado possui o papel de promover a Justiça, o que significa verificar a conformidade da discricionariedade com a lei e também com os princípios jurídicos. ${ }^{97}$ Nesse mesmo sentido, já se manifestou Krell:

Não há mais dúvidas, no Brasil, de que todo e qualquer ato administrativo, inclusive o ato discricionário e também aquele decorrente da valoração administrativa dos conceitos indeterminados de prognose, é suscetível de um controle judicial mínimo, baseado nos princípios constitucionais e nos princípios gerais de Direito. Na atual fase "póspositivista", que foi instaurada com a ampla positivação dos princípios gerais de Direito nos novos textos constitucionais, os atos administrativos discricionários não devem ser controlados somente por sua legalidade, mas por sua juridicidade. ${ }^{98}$

Com efeito, a intervenção jurisdicional passou a envolver o exame dos motivos, da finalidade e da causa do ato, a fim de se verificar se os meios são aptos - adequados - para se atingir aos fins propostos e assegurados constitucionalmente. ${ }^{99}$

94 Celso Antônio Bandeira de Mello, Curso de direito administrativo, op. cit.

95 Maria Sylvia Zanella Di Pietro, Direito administrativo, op. cit.

96 Dentre os doutrinadores que mantêm o entendimento clássico de que o mérito dos atos administrativos discricionário é intocável, fundados nas lições de Fagundes, destacam-se Cretella Júnior (Curso de direito administrativo, op. cit., p. 255) e Gasparini (Direito administrativo, op. cit., p. 92).

97 Hely Lopes Meirelles, Direito administrativo brasileiro, op. cit., p. 123.

98 Krell apud Luiz Nunes Pegoraro, Controle jurisdicional dos atos administrativos discricionários, op. cit., p. 126.

99 Sergio Cruz Arenhart, As ações coletivas e o controle das políticas públicas pelo Poder Judiciário, op. cit. 
Tal intervenção, a seu turno, permite a análise de mérito do ato administrativo, desde que este seja analisado sob o seu aspecto jurídico. ${ }^{100}$ Nesse sentido, assim explica Assunção:

Para a perquirição da motivação, da causa e mesmo da finalidade do ato administrativo atacado em juízo, o magistrado precisa adentrar no seu mérito. Isso não significa afirmar que o Poder Judiciário usurpará da Administração Pública a análise sobre a conveniência e oportunidade da medida. Não. Mas essa conveniência e oportunidade devem se sujeitar à legalidade (em sentido amplo), competindo ao Judiciário, detentor do monopólio da jurisdição, verificar in concreto essa sujeição. ${ }^{101}$

Nesse trâmite, o juízo deverá conjugar a análise do ato no caso concreto com os princípios constitucionais, com destaque a razoabilidade e a proporcionalidade, de modo a enfrentar situações que, não obstante aparentem guardar respaldo com a legalidade, retratam verdadeiro abuso de poder. ${ }^{102}$

Os princípios da razoabilidade e da proporcionalidade, ${ }^{103}$ segundo Meirelles, deverão ser observados para se averiguar se houve pertinência entre a finalidade e os padrões de oportunidade e conveniência. Para o mesmo autor, o objetivo é a "proibição do excesso", vez que visa verificar se houve compatibilidade entre os meios e os fins, a fim de que se evitem restrições desnecessárias ou abusivas por parte da administração pública. ${ }^{104}$

${ }^{100}$ RIO GRANDE DO SUL. Tribunal de Justiça. Jurisprudência. AC nº 70021811302, op. cit.

101 ASSUNÇÃO, Matheus Carneiro. O controle judicial dos atos administrativos discricionários à luz da jurisprudência do STF e do STJ. Jus Navigandi, Teresina, ano 11, n. 1078, 14 jun. 2006. Disponível em: <http://jus.com.br/revista/texto/8508/o-controle-judicial-dos-atos-administra tivos-discricionarios-a-luz-da-jurisprudencia-do-stf-e-do-stj>. Acesso em: 1o out. 2011.

102 José dos Santos Carvalho Filho, Manual de direito administrativo, op. cit., p. 36.

${ }^{103}$ Não há de se negar a celeuma envolvendo a suposta irracionalidade metodológica do princípio da proporcionalidade por Habermas. Para o referido autor, quanto mais as controvérsias políticas se aproximam dos princípios constitucionais, mais se assemelham do discurso moral, o qual depende de convicções pessoais de fé. HABERMAS, Jürgen. A inclusão do outro. São Paulo: Loyola, 2002. p. 102-103. Nesse sentido, o direito e a moral devem ser institutos que se complementem, de forma que o direito positivo possa buscar sua legitimidade no direito moral (Ibid., 288-289). Não há de se contestar a existência de divergências entre direito e moral que o estudo do que se considera razoável pode levantar. Assim, apesar de conhecer a polêmica do debate, não se ignora o peso das críticas, as quais, em virtude da natureza do trabalho monográfico, não se terá condições de aprofundar neste estudo. Para maior aprofundamento do tema sugere-se a leitura da obra citada de Habemas.

104 Hely Lopes Meirelles, Direito administrativo brasileiro, op. cit., p. 94-95. 
Desse modo, com base nos mencionados princípios, será admitido controle pela via judicial para se verificar se o agente administrativo atuou no caso concreto observando a finalidade da norma aplicada. ${ }^{105}$

Para melhor compreensão dos estudos, vale destacar as palavras de Celso Antônio Bandeira de Mello:

Nada há de surpreendente, então, em que o controle jurisdicional dos atos administrativos, ainda que praticados em nome de alguma discrição, se entenda necessária e insuperável a investigação dos motivos, da finalidade e da causa do ato. Nenhum empeço existe a tal proceder, pois é meio - e, de resto, fundamental - pelo qual se pode garantir do atendimento da lei, a afirmação do direito. ${ }^{106}$

A intervenção do Judiciário nos motivos consiste no reexame dos pressupostos fáticos e análise das provas, com a finalidade de verificar se o agente administrativo agiu nos limites da discricionariedade, ou seja, se os motivos indicados para a prática do ato são mesmo verdadeiros - teoria dos motivos determinantes, já mencionada anteriormente. ${ }^{107}$

O exame da finalidade realizado pela via judicial consiste em verificar se a administração utilizou seu poder discricionário para realmente atingir a finalidade legal. Caso o agente aja em descompasso com tal finalidade, seja nas hipóteses em que for movido por interesses pessoais, ou nas hipóteses em que, embora persiga um fim de interesse público, este seja estranho à categoria de interesses comportados em sua competência, pode-se dizer que houve desvio de poder. ${ }^{108}$

A intervenção para análise da causa consiste em verificar se a relação entre o motivo (pressuposto de fato) e o conteúdo está de acordo com a finalidade prevista em lei, ou seja, se guarda "nexo lógico de pertinência com a decisão tomada, em face da finalidade que, em direito, cumpre a atender" ${ }^{109}$

A jurisprudência vem caminhando nesse sentido. Veja-se o entendimento do Supremo Tribunal Federal: ${ }^{110}$

105 Celso Antônio Bandeira de Mello, Curso de direito administrativo, op. cit., p. 953-954.

106 Ibid., p. 967.

107 Maria Sylvia Zanella Di Pietro, Direito administrativo, op. cit., p. 218.

108 Celso Antônio Bandeira de Mello, Curso de direito administrativo, op. cit., p. 970-971.

109 Id., Discricionariedade e controle jurisdicional, op. cit., p. 403.

110 Assim também vem decidindo o STJ e vários tribunais em recorrentes decisões: STJ Resp 778.648/PE, Recurso Especial 2005/0146395-7. Ministro Mauro Campbell Marques. 2 T., 
AGRAVO INTERNO. AÇÃO DIRETA DE INCONSTITUCIONALIDADE. ATO NORMATIVO MUNICIPAL. PRINCÍPIO DA PROPORCIONALIDADE. OFENSA. INCOMPATIBILIDADE ENTRE O NÚMERO DE SERVIDORES EFETIVOS E EM CARGOS EM COMISSÃO. I - Cabe ao Poder Judiciário verificar a regularidade dos atos normativos e de administração do Poder Público em relação às causas, aos motivos e à finalidade que os ensejam. II - Pelo princípio da proporcionalidade, há que ser guardada correlação entre o número de cargos efetivos e em comissão, de maneira que exista estrutura para atuação do Poder Legislativo local. III - Agravo improvido. ${ }^{111}$

Nesse trâmite, conforme já afirmado, a jurisprudência também vem mudando seu entendimento - embora alguns julgadores ainda estejam filiados ao posicionamento clássico da não intervenção do Poder Judiciário no mérito dos atos administrativos discricionários - a fim de fiscalizar se foram atendidos os ditames legais e aos princípios constitucionais.

Vale destacar as palavras de Pegoraro:

No uso da discricionariedade, o administrador deve utilizar a hermenêutica para aclarar possíveis dúvidas e valorar os conceitos jurídicos indeterminados. Os conceitos de conveniência e oportunidade relacionados com o mérito do ato administrativo já não são mais vistos como um enigma jurídico, pois vinculados aos dogmas constitucionais. O Magistrado deve verificar, no caso concreto, a conformidade com os princípios constitucionais da legalidade, da proporcionalidade, da razoabilidade, da moralidade dentre outros, constituindo verdadeira restrição da liberdade de escolha do administrador. ${ }^{112}$

j. 6/11/2008. DJe, Brasília, DF, 1o dez. 2008; TJMG no 1.0672.98.008062-2/001(1). Relator des. Dárcio Lopardi Mendes, j. 3/8/2006. DJMG, Belo Horizonte, 5 set. 2006; TJSP no 9092261 50.2008.8.26.0000. Relator Marrey Uint, j. 17/5/2011. DJSP, São Paulo, 23 maio 2011; TJRS. AC no 70021811302. Relator des. Adão Sérgio do Nascimento Cassiano, j. 12/3/2008, DJRS, Rio Grande do Sul, 15/4/2008; TRF 5 a região AC no 342.739-PE. Relator des. Francisco Cavalcanti, j. 30/11/2004. DJPE, Recife, 18 abr. 2005.

111 BRASIL. Supremo Tribunal Federal. AgR no 365.368/SC. Ag. Regimental no Recurso Extraordinário. 1. T. Relator ministro Ricardo Lewandowski, j. 22/5/2007. Diário de Justiça, Brasília, DF, 29 maio 2007. Disponível em:<www.stf.jus.br/portal/jurisprudencia/pesquisarJurisprudencia. asp>. Acesso em: $1^{\circ}$ out. 2011.

112 Luiz Nunes Pegoraro, Controle jurisdicional dos atos administrativos discricionários, op. cit., p. 182. 


\section{Conclusão}

Por todo o exposto, percebe-se que, em decorrência de todo processo de constitucionalização do direito administrativo e de judicialização, o papel do Poder Judiciário foi ampliado, como meio de suprir as inércias dos demais poderes e concretizar as garantias estabelecidas na Constituição.

Como consequência, uma vez ampliado tal poder, a discricionariedade conferida à administração restou reduzida, uma vez que o administrador ao praticar um ato administrativo deve observar não apenas a lei em sentido estrito, como também a Constituição como um todo.

Assim, os doutrinadores vêm abandonando a corrente clássica ora mencionada, de forma que o mérito, antes intocável, passou a ser objeto de análise, desde que conjugado com os princípios consagrados na Constituição, como meio de se coibir abusos de poder ou eventuais negativas ao texto constitucional por parte dos agentes da administração.

No entanto, essa ampliação do controle jurisdicional não pode ir ao extremo, a ponto de substituir o papel do administrador. Justamente por isso, o Poder Judiciário, dependendo do caso concreto, poderá analisar os atos discricionários quando estes estamparem alguma ilegalidade, abuso de poder, injustiça ou irrazoabilidade, e, em hipóteses excepcionais, poderá até mesmo proferir decisões mandamentais de modo a garantir os princípios e garantias constitucionais.

\section{Referências}

ARENHART, Sergio Cruz. As ações coletivas e o controle das políticas públicas pelo Poder Judiciário. Jus Navigandi, Teresina, ano 10, n. 777, 19 ago. 2005. Disponível em: <http://jus.com.br/revista/texto/7177/as-acoes-coletivase-o-controle-das-politicas-publicas-pelo-poder-judiciario>. Acesso em: $1^{\text {o }}$ out. 2011.

ASSUNÇÃO, Matheus Carneiro. O controle judicial dos atos administrativos discricionários à luz da jurisprudência do STF e do STJ. Jus Navigandi, Teresina, ano 11, n. 1078, 14 jun. 2006. Disponível em: <http://jus.com.br/revista/ texto/8508/o-controle-judicial-dos-atos-administrativos-discricionarios-a-luzda-jurisprudencia-do-stf-e-do-stj>. Acesso em: 1o out. 2011. 
BARROSO, Luis Roberto. Judicialização, ativismo judicial e legitimidade democrática. Consultor Jurídico, São Paulo, 2008. Disponível em: <www.conjur. com.br/2008-dez-22/judicializacao_ativismo_legitimidade_democratica>. Acesso em: 1o out. 2011.

BARROSO, Luis Roberto. Neoconstitucionalismo e constitucionalização do direito. O triunfo tardio do direito constitucional no Brasil. Jus Navegandi, Teresina, ano 10, n. 851, 1o nov. 2005. Disponível em: <http://jus.com.br/ revista/texto/7547>. Acesso em: 5 jun. 2012.

BINENBOJM, Gustavo. Uma teoria do direito administrativo: direitos fundamentais, democracia e constitucionalização. 2. ed. Rio de Janeiro: Renovar, 2008.

BONAVIDES, Paulo. Curso de direito constitucional. 15. ed. São Paulo: Malheiros, 2004.

BRASIL. Constituição da República Federativa do Brasil. Brasília, DF: Senado, 1988.

. Superior Tribunal de Justiça. Resp 778.648/PE, 2 T. Relator Mauro Campbell Marques. Diário de Justiça, Brasília, DF, 1o dez. 2008. Disponível em: $<$ www.stj.jus.br/SCON/>. Acesso em: 11 nov. 2011.

. Superior Tribunal de Justiça. REsp no 429.570/GO. 2. T. Relatora ministra Eliana Calmon. Diário de Justiça, Brasília, DF, 22 mar. 2004. Disponível em: $<$ www.stj.jus.br/SCON/>. Acesso em: 1o out. 2011.

. Supremo Tribunal Federal. AgR no 365.368/SC. Ag. Regimental no Recurso Extraordinário. 1. T. Relator ministro Ricardo Lewandowski, j. 22/5/2007. Diário de Justiça, Brasília, DF, 29 maio 2007. Disponível em: <www. stf.jus.br/portal/jurisprudencia/pesquisarJurisprudencia.asp $>$. Acesso em: 1 o out. 2011.

. Supremo Tribunal Federal. Políticas Públicas - Intervenção Judicial - "Reserva do Possível" (Transcrições). Informativo no 345, Brasília, 26/30 abr. 2004. Disponível em: <www.stf.jus.br/arquivo/informativo/documento/ informativ o345.htm>. Acesso em: 1o out. 2011.

. Supremo Tribunal Federal. RE no 410.715/AgR/SP. Ag. Reg. no Recurso Extraordinário. Relator ministro Celso de Mello, j. 22/11/2005. Diário de Justiça, Brasília, DF, 10 dez. 2005. Disponível em: <www.stf.jus.br/portal/ jurisprudencia /pesquisarJurisprudencia.asp>. Acesso em: 1o out. 2011. 
. Supremo Tribunal Federal. Súmula nº 473: A administração pode anular seus próprios atos, quando eivados de vícios que os tornam ilegais, porque deles não se originam direitos; ou revogá-los, por motivo de conveniência ou oportunidade, respeitados os direitos adquiridos, e ressalvada, em todos os casos, a apreciação judicial. Disponível em: <www.dji.com.br/normas_ inferiores/regimento_interno_e_sumula_stf/stf_0473.htm>. Acesso em: 1o out. 2011.

- Tribunal Regional Federal (5. Região). AC no 342.739. Processo nº 2002.83.00.009457-0. Relator Francisco Cavalcanti, 2002. Disponível em: <www.trf5.jus.br/Jurisprudencia/index.jsp>. Acesso em: 11 nov. 2011.

CANOTILHO, José Joaquim Gomes. Direito constitucional. 6. ed. Coimbra: Almedina, 1993.

CARVALHO FILHO, José dos Santos. Manual de direito administrativo. 10. ed. Rio de Janeiro: Lumen Juris, 2003.

CARVALHO, Kildare Gonçalves de. Direito constitucional. 14. ed. Belo Horizonte: Del Rey, 2008.

CRETELLA JÚNIOR, José. Curso de direito administrativo. 18. ed. Rio de Janeiro: Forense, 2003.

DI PIETRO, Maria Sylvia Zanella. Direito administrativo. 23. ed. São Paulo: Atlas, 2010.

. Discricionariedade administrativa na Constituição de 1988. São Paulo: Atlas, 1991.

FAGUNDES, Miguel Seabra. O controle dos atos administrativos pelo Poder Judiciário. 8. ed. Rio de Janeiro: Forense, 2010.

FARIA, Edimur Ferreira de. Controle do mérito do ato administrativo pelo Judiciário. Belo Horizonte: Fórum, 2011.

. Curso de direito administrativo positivo. 2. ed. Belo Horizonte: Del Rey, 1999.

GASPARINI, Diógenes. Direito administrativo. 8. ed. São Paulo: Saraiva, 2003.

HABERMAS, Jürgen. A inclusão do outro. São Paulo: Loyola, 2002.

LIMA, Rogério Medeiros Garcia. O direito administrativo e o Poder Judiciário. Belo Horizonte: Del Rey, 2002. 
MAGALHÃES, José Luiz Quadros de. Direito constitucional. 2. ed. Belo Horizonte: Mandamentos, 2002.

MATTOS, Mauro Roberto Gomes de. A constitucionalização do direito administrativo e o controle de mérito do ato administrativo discricionário pelo Poder Judiciário. Jus Navegandi, Teresina, ano 10, n. 686, 22 maio 2005. Disponível em: <http://jus.com.br/revista/texto/6756/a-constitucionalizacaodo-direito-administrativo-e-o-controle-de-merito-do-ato-administrativodiscricionario-pelo-poder-judiciario>. Acesso em: 13 nov. 2011.

MEIRELLES, Hely Lopes. Direito administrativo brasileiro. 36. ed. São Paulo: Malheiros, 2010.

MELLO, Celso Antônio Bandeira de. Curso de direito administrativo. 26. ed. São Paulo: Malheiros, 2009.

. Discricionariedade e controle jurisdicional. 2. ed. São Paulo: Malheiros, 2010. MENDES, Gilmar Ferreira; COELHO, Inocêncio Mártires; BRANCO, Paulo Gustavo Gonet. Curso de direito constitucional. 4. ed. São Paulo: Saraiva, 2009.

MINAS GERAIS. Tribunal de Justiça. Jurisprudência $n^{\underline{o}}$ 1.0672.98.0080622/001(1). Relator: des. Dárcio Lopardi Mendes, 2010. Disponível em: <www. tjmg.jus.br/juridico/jt_>. Acesso em: 1ํout. 2011.

MOTA, Marcel Moraes. Racionalidade e discricionariedade administrativa. Conpedi, Brasília, n. 20, 21/22 nov. 2008. Disponível em: <www.conpedi.org. br/manaus/arquivos/anais/brasilia/12_178.pdf>. Acesso em: 5 jun. 2012.

OLIVEIRA, Marcelo Andrade Cattoni de. Direito constitucional. Belo Horizonte: Mandamentos, 2002.

PEDRON, Flávio Quinaud. Algumas considerações sobre a interpretação de Robert Alexy sobre a tese da única resposta correta de Ronald Dworkin. Âmbito Jurídico, Rio Grande, n. 19, 30 nov. 2004. Disponível em: <www.ambitojuridico.com.br/site/index.php?n_link=revista_artigos_leitura\&artigo_ id=4999>. Acesso em: 1o out. 2011.

PEGORARO, Luiz Nunes. Controle jurisdicional dos atos administrativos discricionários. Campinas, SP: Servanda Editora, 2010.

PEREIRA JUNIOR, Jessé Torres. Controle judicial da administração pública, da legalidade estrita à lógica do razoável. 2. ed. Belo Horizonte: Fórum, 2009. 
PESTANA, Marcio. Direito administrativo brasileiro. Rio de Janeiro: Campus Jurídico, 2008.

RIO GRANDE DO SUL. Tribunal de Justiça. Jurisprudência. AC nº 70021811302. Des. Adão Sérgio do Nascimento Cassiano. DJ, Porto Alegre, 15 abr. 2008. Disponível em: <www.tjrs.jus.br/busca/?tb=jurisnova\&partialfi elds=tribunal\%3ATribunal\%2520de\%2520Justi\%25C3\%25A7a\%2520do\%2520 RS.(TipoDecisao\%3Aac\%25C3\%25B3rd\%25C3\%25A3o I TipoDecisao\%3Amo nocr\%25C3\%25A1tica | TipoDecisao:null)\&t=s\&pesq=ementario. $>$. Acesso em: 11 nov. 2011.

SÃO PAULO. Tribunal de Justiça. AC no 151.580 . Revista de Direito Administrativo, São Paulo, n. 89, v. 134, p. 63, 1983.

. Tribunal de Justiça. Jurisprudência no 9092261-50.2008.8.26.0000. Relator

Marrey Uint, 2008. Disponível em: <https://esaj.tjsp.jus.br/cjsg/consultaComp leta.do>. Acesso em: 1ํo out. 2011.

STRECK, Lênio Luiz. Hermenêutica jurídica e(m) crise: uma exploração hermenêutica da construção do direito. Porto Alegre: Livraria do Advogado, 2004.

ZIMMER JÚNIOR, Aloísio. Curso de direito administrativo. 3. ed. Porto Alegre: Verbo Jurídico, 2009. 